Ardura A., Zaiko A., Martinez J.L., Samuiloviene A., Semenova A., Garcia-Vazquez E. 2015. eDNA and specific primers for early detection of invasive species- a case study on the bivalve Rangia cuneata, currently spreading in Europe. Marine Environmental Research, 112(B): 48-55.

doi:10.1016/j.marenvres.2015.09.013

\title{
eDNA and specific primers for early detection of invasive species-a case study on the bivalve Rangia cuneata, currently spreading in Europe.
}

Alba Ardura,2-a , Anastasija Zaiko, ${ }^{2,3}$, Jose L. Martinez ${ }^{4}$, Aurelija Samulioviene ${ }^{2}$, Anna Semenova $^{5}$, Eva Garcia-Vazquez ${ }^{1}$

1: Department of Functional Biology, University of Oviedo. C/ Julian Claveria s/n. 33006 - Oviedo, Spain.

2: Marine Science and Technology Centre, Klaipeda University. H. Manto 84, LT 92294, Klaipeda, Lithuania.

3: Coastal and Freshwater Group, Cawthron Institute, 98 Halifax Street East, 7010 Nelson, New Zealand

4: Unit of DNA Analysis, Scientific-Technical Services, University of Oviedo. Edificio Severo Ochoa, Campus del Cristo, 33006 - Oviedo, Spain. Russia

5: Atlantic Research Institute of Marine Fisheries and Oceanography, Kaliningrad,

Alba Ardura: (a) corresponding author: alarguti@ hotmail.com

Anastasija Zaiko: anastasija@ corpi.ku.lt

Jose L. Martinez: secuenciacion@ spi.uniovi.es

Aurelija Samulioviene: aurelija@corpi.ku.lt

Anna Semenova: a.s.semenowa@gmail.com

Eva Garcia-Vazquez: egv@uniovi.es 
Ardura A., Zaiko A., Martinez J.L., Samuiloviene A., Semenova A., Garcia-Vazquez E. 2015. eDNA and specific primers for early detection of invasive species- a case study on the bivalve Rangia cuneata, currently spreading in Europe. Marine Environmental Research, 112(B): 48-55.

doi:10.1016/j.marenvres.2015.09.013

\section{Abstract}

Intense human activities facilitate the successful spread and establishment of nonindigenous aquatic organisms in marine and freshwater ecosystems. In some cases such intrusions result in noticeable and adverse changes in the recipient environments. In the Baltic Sea, the discovery and rapid initial spread of the North American wedge clam Rangia cuneata represents a new wave of invasion which may trigger unpredictable changes of the local benthic communities. In this study we present a species-specific DNA-based marker developed in silico and experimentally tested on environmental samples. Marker specificity and sensitivity were assessed in vitro from water samples containing different mixtures of the target species and other five bivalves currently present in the region: the native Cerastoderma glaucum, Macoma balthica and Mytilus trossulus, the invasive Dreissena polymorpha and the cryptogenic Mya arenaria. Crossspecies amplification was not found in any case. The method allows to detecting at least $0.4 \mathrm{ng}$ of Rangia cuneata DNA per $\mu \mathrm{l}$, and $0.1 \mathrm{~g}$ of tissue per liter of water. Finally, the marker performance was assessed in water samples from the Baltic Sea and Vistula Lagoon. The coincidence between independent visual observations of Rangia cuneata and positive PCR amplification of the marker from the water samples confirmed the efficiency of this highly reproducible, fast, and technically easy method. Rangia cuneata traces can be detected from environmental DNA even when the population is sparse and small, enabling rapid management responses and allowing to track the invasion dynamics.

Highlights: Traditional sampling tools are insufficient to detect new invasions. Developing and testing species-specific molecular markers for early detection of invasive species. Assessment of Rangia cuneata distribution using eDNA. Speciesspecific markers for screening environmental samples.

Key words: Baltic Sea, non-indigenous species, species-specific marker, Rangia cuneata, eDNA, Vistula Lagoon. 
Ardura A., Zaiko A., Martinez J.L., Samuiloviene A., Semenova A., Garcia-Vazquez E. 2015. eDNA and specific primers for early detection of invasive species- a case study on the bivalve Rangia cuneata, currently spreading in Europe. Marine Environmental Research, 112(B): 48-55.

doi:10.1016/j.marenvres.2015.09.013

\section{Introduction}

Marine alien species are global drivers of the ecosystem change, and a threat to native biodiversity and marine resources (Molnar et al., 2008). Many aquatic communities are impaired by the uncontrolled spread of invaders (Horgan and Mills, 1997; Molnar et al., 2008), and activities such as aquaculture, fishing and shellfish harvesting may be severely affected (e.g. Hayes and Silwa, 2003; Neill et al., 2006). Even food security, human health and economy are threatened by biological invasions in many regions (Nuñez and Pauchard, 2010).

In this context, the emphasis is put on preventive measures such as risk assessments and early detection of potential marine pests (Behrens et al., 2005; Delaney et al., 2008). Every new invasion is enlisted by scientists and managers, and efforts are focused on explaining its impact the recipient ecosystem, predicting the invasion outcome and preventing (if possible) from further spread. However, new invasions are often detected years after introduction when populations are too abundant and widespread to allow eradication (Geller et al., 1997; Freire et al., 2014). Moreover, when invasions are declared few effective tools are available for national agencies to control them and minimize their effects on the ecosystem health and economy (Olenin et al., 2011; Pochon et al., 2013).

A new introduction of alien species detected in Europe in the last decade was Rangia cuneata, a clam that inhabits low salinity waters (Parker, 1966). It is native to the Gulf of Mexico where it is found predominantly in estuaries. The first record of this species out of America was in the harbor of Antwerp, Belgium (Verween et al, 2006). A few small individuals were found in 2005, but from February 2006 onwards many individuals were found in the pipes of the cooling water system of an industrial plant (Verween et al., 2006). The extremely rapid spread of this species was confirmed soon in other regions of Europe. Only four years later, Rangia cuneata was recorded in the Vistula Lagoon of the Baltic Sea (September 2010), and in 2011 this clam had invaded a large area of the bay with up to 4,040 individuals $/ \mathrm{m}^{2}$ in the areas adjacent to the Kaliningrad Sea channel (Rudinskaya and Gusev, 2012). The introduction of Rangia cuneata into the Vistula Lagoon was attributed to ballast waters of ships coming from 
Ardura A., Zaiko A., Martinez J.L., Samuiloviene A., Semenova A., Garcia-Vazquez E. 2015. eDNA and specific primers for early detection of invasive species- a case study on the bivalve Rangia cuneata, currently spreading in Europe. Marine Environmental Research, 112(B): 48-55.

doi:10.1016/j.marenvres.2015.09.013

areas where these clams were naturalized (Verween et al., 2006; Rudinskaya and Gusev, 2012). The species may become a trigger of adverse transformations in the local benthic communities of the Baltic Sea (Rudinskaya and Gusev, 2012). It advances very rapidly, since in May 2013 several small individuals of Rangia cuneata were already found in benthic samples from the Lithuanian coast (Solovjeva, 2014).

Rangia cuneata has also a history of invasions outside Europe. It was transported from its natal region in the Gulf of Mexico to the NW Atlantic accompanying Crassostrea virginica stocks introduced in Chesapeake Bay (Pfitzenmeyer and Drobeck, 1964). It has thriven there and (in concurrence with other invaders) has adversely altered the ecosystem (e.g. Ruiz et al., 1999). It is highly tolerant to harsh environmental conditions, thus it has a greater probability of being transported alive and settle down in new environments than other less tolerant aquatic species (Valentine and Sklenar, 2004; Wakida-Kusunoki and MacKenzie, 2004; Wolff, 1999). Environmental conditions unfavorable for many native species have triggered sudden outbursts of Rangia cuneata in the recipient ecosystem (Kerckhof et al., 2007; Verween et al., 2006).

From the current climate change that is inducing changes in species distributions (Parmesan and Yohe, 2003; Hijmans and Graham, 2006; Seo et al., 2009), and the high tolerance to adverse conditions of Rangia cuneata, it can be a good candidate for the World's "black list" of invaders. It is already recognized as highly invasive by the Invasive Species Specialist Group (ISSG database: www.issg.org/; DAISIE database: www.europe-aliens.org/). Therefore, detecting its occurrence at a low density prior full settlement is crucial to increase the effectiveness of eradication or containment measures (Jerde et al., 2011).

The traditional sampling methods are insufficient for early detecting new invasions, especially in aquatic environments where organisms are not always visible and can be hidden underwater. Several studies demonstrate the efficiency of environmental DNA (eDNA) as a tool for species detection in aquatic environments (Ficetola et al., 2008; Dejean et al., 2011; Jerde et al., 2011; Taberlet et al., 2012; Thomsen et al., 2012). DNA extracted directly from water and sediment samples contains exfoliated cells, small eggs and larvae that can be overlooked in routine surveys. Species-specific molecular markers can be PCR-amplified from eDNA allowing to the detection of organisms of 
Ardura A., Zaiko A., Martinez J.L., Samuiloviene A., Semenova A., Garcia-Vazquez E. 2015. eDNA and specific primers for early detection of invasive species- a case study on the bivalve Rangia cuneata, currently spreading in Europe. Marine Environmental Research, 112(B): 48-55.

doi:10.1016/j.marenvres.2015.09.013

interest, such as threatened species (Thomsen et al., 2012) and pests from early invasion fronts (Jerde et al., 2011). Other sophisticated molecular methods for detection of marine invertebrate larvae involve robotized processes or in situ hybridization (Pradillon et al., 2007; Jones et al., 2008).

The objective of the present study was to develop and test the species-specific molecular markers for early detection and distribution assessment of Rangia cuneata from environmental samples. The aim was to create a PCR-based method for analyzing eDNA with normal (unlabeled) primers and PCR products directly visualized in agarose gel. The possible applications of the species-specific markers for biosecurity and monitoring issues were also discussed in the current account.

\section{Material and Methods}

\section{Mollusk and water samples}

Five Rangia cuneata adult specimens around $2 \mathrm{~cm}$ length were collected from the Vistula Lagoon in May 2013, which is its current distribution area within the Baltic Sea (Figure 1). They were identified de visu by experts and served for reference sequencing and experimental work. The morphotaxonomical identification of the Rangia cuneata mollusks was conducted as described in Rudinskaya and Gusev (2012) (Figure 1). Briefly, diagnostic features that differentiate the species from other Baltic mollusks are the tilt and the position of the shell tops, the shell top bent inside and shifted toward the front part of the shell. Although these traits are not fully developed in young specimens, they are clear enough for distinguishing Rangia cuneata from the rest of common bivalve species inhabiting brackish waters of the Baltic Sea. For the experiments on specificity and sensitivity of the new marker, other five bivalve mollusk species present in the area and having planktonic larvae were sampled from the Lithuanian coast of the Baltic Sea and the Curonian Lagoon: the native Cerastoderma glaucum, Macoma balthica, Mytilus trossulus; the already established invader Dreissena polymorpha and cryptogenic Mya arenaria. Five voucher adults from each species were sampled. 
Ardura A., Zaiko A., Martinez J.L., Samuiloviene A., Semenova A., Garcia-Vazquez E. 2015. eDNA and specific primers for early detection of invasive species- a case study on the bivalve Rangia cuneata, currently spreading in Europe. Marine Environmental Research, 112(B): 48-55.

doi:10.1016/j.marenvres.2015.09.013

Environmental samples were collected in duplicate from Lithuanian coastal zone (close to locations where Rangia cuneata was previously observed) on May 20 and September 2, 2014 (Figure 2, Table 1). Additionally 9 samples were collected from 5 monitoring stations within the Vistula Lagoon on June 4 and July 22, 2014. Taking into account, that repeated or even continuous spawning of Rangia cuneata has been reported at water temperature exceeding $15^{\circ} \mathrm{C}$ and salinities below 15 PSU (Fairbanks, 1963; Cain, 1972) the sampling dates and locations were selected as presumably favorable for the larvae occurrence. Samples from the coastal zone were collected with the WP2 plankton net (5 m length, $100 \mu \mathrm{m}$ mesh size), vertically towed $5-10 \mathrm{~m}$, depending on the depth. Samples from the Vistula lagoon were collected using 6L discrete water sampler from 3 depths (surface, intermediate and near-bottom) and concentrated by filtering through $70 \mu \mathrm{m}$ mesh. One sample from every location and depth was analyzed de visu by an expert taxonomist, in order to verify the presence of Rangia cuneata larvae. Another sample was vacuum-filtered through $0.12 \mu \mathrm{m}$ Nuclepore $^{\mathrm{TM}}$ membrane, and preserved thereafter with $96 \%$ ethanol for the future bulk DNA extraction.

\section{DNA extraction}

Total DNA was extracted from foot muscle of five individuals per species employing a method based on silica gel columns (QIAmp DNA Mini kit, Qiagen), following manufacturer's instructions. The tubes were stored at $4^{\circ} \mathrm{C}$ for immediate DNA analysis, and aliquots were frozen at $-20^{\circ} \mathrm{C}$ for long-time preservation.

eDNA was extracted from the filters using the PowerWater DNA Isolation kit (MoBio Laboratories Inc., Carlsbad, CA) following manufacturer's recommendations.

DNA was quantified in agarose gel comparing with DNA mass ladder (Perfect 100 bp DNA Ladder from EURx) and with an absorbance method (BioPhotometer by Eppendorf).

\section{Design of species-specific primers}

The design of the species-specific primers was based on reference nucleotide sequences of $16 \mathrm{~S}$ rDNA obtained from GenBank, plus the sequences obtained from the 
Ardura A., Zaiko A., Martinez J.L., Samuiloviene A., Semenova A., Garcia-Vazquez E. 2015. eDNA and specific primers for early detection of invasive species- a case study on the bivalve Rangia cuneata, currently spreading in Europe. Marine Environmental Research, 112(B): 48-55.

doi:10.1016/j.marenvres.2015.09.013

mollusk samples as described below. To design the new primers, sequences were aligned using the ClustalW tool (Thompson et al., 1994) included in the BioEdit Sequence Alignment Editor software (Hall, 1999). A region within the 16S rRNA gene conserved in Rangia cuneata but with different nucleotide sequence in the rest of considered species was searched. Such a region, which is located within the region amplified by Palumbi (1996) with the primers 16Sar and 16Sbr, was employed for designing a Rangia cuneata specific forward primer. As reverse primer we have used the generalist 16Sbr described by Palumbi (1996), so that the region amplified with the new primer is nested within the region described by Palumbi (1996).

\section{PCR amplification and sequencing}

The amplification reaction of the longer 16S rDNA fragment employing the primers 16Sar and 16Sbr described by Palumbi (1996) was performed in a total volume of $20 \mu 1$, with Promega (Madison, WI), Buffer 1x, $2.5 \mathrm{mM} \mathrm{MgCl} 2,0.25 \mathrm{mM}$ dNTPs, 20 pmol of each primer, approximately $20 \mathrm{ng}$ of template DNA and $1 \mathrm{U}$ of DNA Taq polymerase (Promega), and the following PCR conditions: initial denaturing at $95^{\circ} \mathrm{C}$ for $5 \mathrm{~min}, 35$ cycles of denaturing at $94^{\circ} \mathrm{C}$ for $1 \mathrm{~min}$, annealing at $55^{\circ} \mathrm{C}$ for 1 minute, extension at $72^{\circ} \mathrm{C}$ for 2 minutes and final extension at $72^{\circ} \mathrm{C}$ for 7 minutes.

For the new species-specific primers the PCR conditions were the same except for the annealing temperature that was $50^{\circ} \mathrm{C}$.

PCR products were visualized under UV light on a $1 \%$ agarose gel stained with SimplySafe ${ }^{\mathrm{TM}}$ from EURx.

Sequencing was performed by the DNA sequencing service Macrogen Europe.

The sequences obtained were compared with international databases employing the program BLASTn within the National Center for Biotechnology Information (NCBI, http://www.ncbi.nlm.nih.gov/) for confirming species identification.

\section{Marker validation in vitro and in field samples}

For determining the specificity of the newly designed primers, DNAs of different mollusk species were mixed in different proportions (Table 2). 
Ardura A., Zaiko A., Martinez J.L., Samuiloviene A., Semenova A., Garcia-Vazquez E. 2015. eDNA and specific primers for early detection of invasive species- a case study on the bivalve Rangia cuneata, currently spreading in Europe. Marine Environmental Research, 112(B): 48-55.

doi:10.1016/j.marenvres.2015.09.013

The sensitivity of the primers was experimentally assayed from successive dilutions of Rangia cuneata DNA in distilled water (Table 2).

For the utility of the new primers in environmental samples, three experimental simulated communities were set up dissolving Rangia cuneata tissue (foot muscle) desiccated and manually grinded in water samples as it follows (Table 3):

- $5 \mathrm{mg}$ dry weight of Rangia cuneata in $50 \mathrm{ml}$ of distilled water.

- $5 \mathrm{mg}$ dry weight of Rangia cuneata in $50 \mathrm{ml}$ of marine water from the Ria of Aviles (Bay of Biscay, North Spain). The area is covered of blue mussels Mytilus galloprovincialis (density: >1000/square meter).

- Negative community control 1: $50 \mathrm{ml}$ marine water (same site and sampling time as above).

- Negative control with distilled water.

Additionally, water samples (1 liter) from two locations within the Baltic Sea coast and five within Vistula Lagoon (Figure 2) were taken in 2014 for amplification of the developed marker.

Linear regression model with a robust fitting algorithm was applied to relate the yielded Rangia cuneata amplification product quantities to the abundances of the visually observed larvae in the samples (implemented in the R v3 statistical computing environment).

\section{Results}

\section{Primer designed and its performance}

A total of $2516 \mathrm{~S}$ rDNA sequences representing the 25 different species were retrieved from the GenBank (Supplementary table 1). They corresponded to a wide range of marine taxonomic groups, including algae, invertebrates and vertebrates. In addition, longer 16SrDNA sequences obtained by PCR with Palumbi (1996) primers for the six analyzed mollusk species were also considered. They were $470 \mathrm{bp}$ long, and were submitted to GenBank where they are available with the accession numbers KP052743-KP052753; correspond to Cerastoderma. glaucum, Dreissena polymorpha, 
Ardura A., Zaiko A., Martinez J.L., Samuiloviene A., Semenova A., Garcia-Vazquez E. 2015. eDNA and specific primers for early detection of invasive species- a case study on the bivalve Rangia cuneata, currently spreading in Europe. Marine Environmental Research, 112(B): 48-55.

doi:10.1016/j.marenvres.2015.09.013

four different haplotypes of Macoma balthica, Mya arenaria, Mytilus trossulus and three different haplotypes of Rangia cuneata.

Designed forward primer within the amplified 16SrDNA region can hybridize only with Rangia cuneata DNA at $50^{\circ} \mathrm{C}$ of annealing temperature, since that region has a different nucleotide composition from the rest of the considered species (see an alignment of several sequences showing the Rangia cuneata specific region in Figure $3)$.

The sequence of the new forward primer designed was:

\section{RC-16Sar: 5’ AAATTTCTTCTAATGATGTGAGG -3’’}

Employing the primer 16Sbr described by Palumbi (1996) as the reverse primer, the pair flanks a region of 205 base pairs (bp) (Figure 3). The alignment with the sequences of the closest species that are available in GenBank (Pseudocardium sachalinense KP090053, Tresus capax KC429311, Spisula solida JF808191, Tresus keenae JX399585, Meropesta nicobarica JN674570) shows that, although they are taxonomically close to each other, there are clear differences at sequence level, especially in the Rangia cuneata-specific primer region (Figure 4).

In DNA extracted from Rangia cuneata voucher specimens the new pair of primers provided clear and clean positive amplification. Only one PCR product of the expected size was obtained, with no secondary bands (Figure 5). The sequences obtained from the amplicons provided high identity when aligned with 16SrDNA of Rangia cuneata (Figure 3), hence proving the amplicons corresponded to the target DNA region.

\section{Specificity and sensitivity of the designed primer}

Rangia cuneata-specific primers yielded positive PCR amplifications of one single band (approx. 200 bp) when Rangia cuneata was present in a sample. Crossamplification was not found in any case (Figure 4); Mya arenaria does not appear on the picture but it did not yield positive amplification with Rangia cuneata primers in any assay. The results of the serial dilutions of Rangia cuneata DNA (Table 2) revealed positive PCR with Rangia cuneata-specific primers down to 1:125 (Table 2, Figure 6). 
Ardura A., Zaiko A., Martinez J.L., Samuiloviene A., Semenova A., Garcia-Vazquez E. 2015. eDNA and specific primers for early detection of invasive species- a case study on the bivalve Rangia cuneata, currently spreading in Europe. Marine Environmental Research, 112(B): 48-55.

doi:10.1016/j.marenvres.2015.09.013

Hence we conclude that the detection limit with the new primer and PCR product visualization in agarose gel is $0.4 \mathrm{ng} / \mu \mathrm{l}$ DNA. The universal primer pairs of Palumbi (1996) exhibited a similar sensitivity, giving positive amplification at 1:100 dilution.

In experimental DNA mixtures (Table 2), Rangia cuneata-specific primers exhibited the same sensitivity as for Rangia cuneata DNA alone: 1:125. With Palumbi (1996) primers positive PCR amplification was obtained from all the samples, as expected. The amplicon was approximately 500 bp that is the expected size (Figures 5 and 7).

\section{$\underline{\text { Marker validation }}$}

In vitro experiments with eDNA samples (simulated communities) validated the performance of primers (Table 3). In the simulated community containing Rangia cuneata tissue, the Rangia cuneata primers (Figure 7) provided positive results for both distilled water (RD) and natural marine water (RM) from Ria of Aviles (1 mg dry weight per $10 \mathrm{ml}$ of water). In the negative control without Rangia cuneata tissue (MW) amplification was not found, as expected since Rangia cuneata is not present in Asturias coast yet (Table 3).

Regarding the field water samples, PCR amplification with Rangia cuneata specific primers was positive for five samples from the Vistula Lagoon and none from the Baltic coast (Figure 8), independently from eDNA concentration (Table 4). False positives were not found. Five true positives (positive PCR amplification and $R$. cuneata larvae observed de visu), four true negatives (no PCR amplification and no $R$. cuneata larvae observed de visu) and four false negatives (three samples of the second semester and one of the first semester from areas with observed $R$. cuneata larvae) were obtained. The Chi-square value of the contingency table corresponding to these results is 3.62 , with a P-value of 0.057 (marginally significant) for 1 d.f. For universal primers (Palumbi, 1996), as expected, we got positive results from all water samples analyzed (Figure 6-right).

As evidenced from the fitted linear regression model (Supplementary figure 1), the amount of the Rangia cuneata DNA product yielded from the positive amplifications in eDNA samples significantly correlated with the larvae abundances reported from the 
Ardura A., Zaiko A., Martinez J.L., Samuiloviene A., Semenova A., Garcia-Vazquez E. 2015. eDNA and specific primers for early detection of invasive species- a case study on the bivalve Rangia cuneata, currently spreading in Europe. Marine Environmental Research, 112(B): 48-55.

doi:10.1016/j.marenvres.2015.09.013

visual analysis of the replicate samples from the same areas $(r=0.88, p<0.001)$. No significant correlation $(\mathrm{r}=-0.37, \mathrm{p}=0.21)$ with the total eDNA concentration was found.

\section{Discussion}

The species-specific marker designed in this study was sensitive and accurate. It could be recommended as a useful tool to detect the presence of Rangia cuneata DNA, even at low concentration and in complex samples containing other species. It has been successfully amplified from real environmental water samples when Rangia cuneata is present (Vistula Lagoon), but not from the Baltic coastal samples where the species as not been detected de visu. Cross-amplification with other mollusk species phylogenetically close to Rangia cuneata (e.g. Mya arenaria) was not detected. These results suggest that these specific markers are robust and cost-efficient for detecting this species from eDNA. This method, could complement traditional monitoring approaches, as also proposed by other authors (Taberlet et al., 2012; Thomsen et al. 2012). It is a practical solution when the visual census gives low-quality results (e.g. for detecting a new-coming scarce species) and/or requires a huge sampling effort (e.g. for sparsely distributed marine species). This is particularly important in the current moment of diminishing budgets, when national monitoring networks carefully consider survey expenses and aim at cost-effective approaches (Aylagas et al., 2014).

Another advantage of this technique is that the target DNA fragment is very short (around $200 \mathrm{bp}$ ) and can thus be PCR amplified even from degraded DNA. This is very important for early species detection because short DNA fragments can persist in the environment for a relatively long time. For example, DNA fragments of approximately $400 \mathrm{bp}$ persist for up to one week at $18^{\circ} \mathrm{C}$ in lake water (Matsui et al., 2001).

Massive (high-throughput) sequencing techniques can also generate PCR products with universal primers from environmental samples or degraded substrates, but require extensive data analysis (Hofreiter et al., 2003; Willerslev et al., 2003; Taberlet et al., 2007). In contrast, the method employed here detects the presence of the target species DNA from the water samples using PCR and a simple electrophoresis in agarose gel, without any other data analysis. This is a good and convenient approach when the target 
Ardura A., Zaiko A., Martinez J.L., Samuiloviene A., Semenova A., Garcia-Vazquez E. 2015. eDNA and specific primers for early detection of invasive species- a case study on the bivalve Rangia cuneata, currently spreading in Europe. Marine Environmental Research, 112(B): 48-55.

doi:10.1016/j.marenvres.2015.09.013

species is known (e.g. next-coming alien species from the adjacent aquatic regions), and the focus is put on its detection rather than general biodiversity assessment. The suggested method is reproducible, fast, and cost-efficient (Leung et al., 2002). Moreover, it does not require any taxonomical expertise (particularly essential when identifying the species at a larval stage) or phylogenetic knowledge. To perform the test only basic technical skills in PCR and gel electrophoresis are needed.

The sensitivity of this marker $(0.4 \mathrm{ng} / \mu \mathrm{l}$ of DNA as resulted from the simulation experiments) is comparable to other methodologies based on NGS approaches (Pochon et al., 2013). As verified from the Rangia cuneata larvae abundance, the marker was able to detect the species when it was above 1900 individual $/ \mathrm{m}^{3}$ (Table 4). This is a fair result for the benthic populations established in the area with abundances up to 5000 individual $/ \mathrm{m}^{2}$ (Rudinskaya and Gusev, 2012). The positive and strong correlation between the estimated quantity of PCR product and Rangia cuneata larvae densities suggests that the marker is sensitive to the abundance of the target species. This may have further implications since it could provide some preliminary metrics, e.g. for the environmental assessment or monitoring within the Marine Strategy Framework Directive. Further development of this marker would include assaying other visualization methodologies more sensitive than agarose gels, like RT-PCR or primers labeled with fluorochromes.

More studies on the detection limits of this marker in the field would be necessary, since eDNA methodology has some limitations (e.g. Bohmann et al., 2014). For example, false negatives can happen if the PCR protocol (and/or the primers designed) fails to anneal on different haplotypes in case of intraspecific polymorphism. In our study we did not find positive PCR amplification from Lithuanian coastal samples, although some Rangia cuneata adults have been detected nearby recently (Solovjeva, 2014). It is not a false negative because Rangia cuneata larvae were not visually detected in the samples, which is totally consistent with eDNA results. The absence of larvae in a zone where adults have been detected could be explained in different ways. Perhaps that coastal population is not self-sustainable yet (e.g. individuals are too sparse to reproduce effectively). Moreover, both adult spawning and larvae lifetime may vary in estuarine and open sea waters (Fairbanks, 1963; Chanley, 1965), and our sampling 
Ardura A., Zaiko A., Martinez J.L., Samuiloviene A., Semenova A., Garcia-Vazquez E. 2015. eDNA and specific primers for early detection of invasive species- a case study on the bivalve Rangia cuneata, currently spreading in Europe. Marine Environmental Research, 112(B): 48-55.

doi:10.1016/j.marenvres.2015.09.013

events did not coincide with larvae occurrence in the zone (e.g. the water temperature in May was lower than that indicated in literature as suitable for Rangia cuneata spawning). On the other hand, the sampling methodology used here was not the optimal for retaining small larvae, since Rangia cuneata larvae size might vary between 5 and $175 \mu \mathrm{m}$ (for height-length-thickness dimensions) and can be missed by the standard plankton net applied for the regional zooplankton monitoring program (100 $\mu \mathrm{m}$ mesh size). In a program specifically designed for monitoring Rangia cuneata, smaller mesh size would be desirable for sampling nets.

The new marker is especially timely because Rangia cuneata is currently starting to spread in the Baltic Sea. It could be applied for monitoring the species invasion dynamics, e.g. for defining the abundance and distribution range of this species within the biopollution assessment (Olenin et al., 2007). In conclusion, we recommend the application of eDNA-based species-specific markers for screening environmental samples and complementing routine monitoring tools. The approach may help to improve the management of biological invasions because with a more efficient early detection, adequate response measures will be earlier adopted and be likely more effective.

\section{Acknowledgments}

This study was funded by the Ministerio de Economia y Competitividad (MINECO, Spain), Reference CGL2013-42415-R; the DEVOTES (DEVelopment Of innovative Tools for understanding marine biodiversity and assessing Good Environmental Status) project funded by the European Union under the 7th Framework Programme, 'The Ocean of Tomorrow' Theme (Grant Agreement No. 308392),www.devotes-project.eu and BIO-C3 (Biodiversity changed investigating causes, consequences and management implications) Project within the BONUS, the joint Baltic Sea Research and Development programme, funded by the EU 7th Framework Programme and Research Council of Lithuania (Grant Agreement No. BONUS-1/2014), www.bio-c3.eu/. A.A. holds a regional postdoctoral Marie Curie grants COFUND-CLARIN. 
Ardura A., Zaiko A., Martinez J.L., Samuiloviene A., Semenova A., Garcia-Vazquez E. 2015. eDNA and specific primers for early detection of invasive species- a case study on the bivalve Rangia cuneata, currently spreading in Europe. Marine Environmental Research, 112(B): 48-55.

doi:10.1016/j.marenvres.2015.09.013

\section{References}

Aylagas E, Borja A and Rodrigues-Ezpeleta N. 2014. Environmental status assessment using DNA metabarcoding: towards a genetic based marine biotic index (gAMBI). PLoS One 9:e90529.

Behrens HL, Leppäkoski E and Olenin S. 2005. Ballast Water Risk Assessment Guidelines for the North Sea and Baltic Sea. Nordtest Technical Report TR 587, 36pp.

Bohmann K, Evans A, Gilbert MTP, Carvalho GR, Creer S, Knapp M, Yu DW and de Bruyn M. 2014. Environmental DNA for wildlife biology and biodiversity monitoring. Trends in Ecology and Evolution, 29:358-367.

Cain TD. 1972. The reproductive cycle and larval tolerances of Rangia cuneata in the James River, Virginia. PhD dissertation. University of Virginia, Charlottesville: 250 pp.

Chanley P. 1965. Larval development of the brakish water mactrid clam, Rangia cuneata. Chesapeake Science, 6(4):209-213.

Dejean T, Valentini A, Duparc A, Pellier-Cuit S, Pompanon F, Taberlet P and Miaud C. 2011. Persistence of environmental DNA in freshwater ecosystems. PloS one, 6(8), e23398.

Delaney DG, Sperling CD, Adams, CS and Leung B. 2008. Marine invasive species: validation of citizen science and implications for national monitoring networks. Biological Invasions, 10:117-128.

Fairbanks LD. 1963. Biodemographic studies of the clam Rangia cuneata Gray. Tulane Studies in Zoology, 10:3-47.

Ficetola et al. 2008. Species detection using environmental DNA from water samples. Biological Letters, 4:423-425.

Freire M, Genzano GN, Neumann-Leitao S and Perez CD. 2014. The nonindigenous medusa Blackfordia virginica (Hydrozoa, Leptothecata) in tropical Brazil: 50 years of unnoticed presence. Biological Invasions, 16:1-5.

Geller JB, Walton ED, Grosholz ED and Ruiz GM. 1997. Cryptic invasions of the crab Carcinus detected by molecular phylogeography. Molecular Ecology, 6:901-906.

Hall A. 1999. BioEdit: a user-friendly biological sequence alignment editor and analysis program for Windows 95/98/NT. Nucleic Acids Symposium Series, 41:95-98.

Hayes KR and Sliwa C. 2003. Identifying potential marine pests - a deductive approach applied to Australia. Marine Pollution Bulletin, 46:91.

Hijmans RJ and Graham CH. 2006. The ability of climate envelope models to predict the effect of climate change on species distributions. Global Change Biology, $12: 2272-2281$.

Hofreiter M, Betancourt JL, Pelliza Sbriller A, Markgraf V and McDonald HG. 2003. Phylogeny, diet, and habitat of an extinct ground sloth from Cuchillo Curá, Neuquén Province, southwest Argentina. Quaternary Research, 59:364-378. 
Ardura A., Zaiko A., Martinez J.L., Samuiloviene A., Semenova A., Garcia-Vazquez E. 2015. eDNA and specific primers for early detection of invasive species- a case study on the bivalve Rangia cuneata, currently spreading in Europe. Marine Environmental Research, 112(B): 48-55.

doi:10.1016/j.marenvres.2015.09.013

Horgan MJ and Mills EL. 1997. Clearance rates and filtering activity of zebra mussel (Dreissena polymorpha): implications for freshwater lakes. Canadian Journal of Fish Aquatic Sciences, 54(2):249-255.

Jerde CL, Mahon AR, Chadderton WL and Lodge DM. 2011. "Sight-unseen" detection of rare aquatic species using environmental DNA. Conservation Letters, $4: 150-157$.

Jones WJ, Preston CM, Marin III R, Scholin CA and Vrijenhoek RC. 2008. A robotic molecular method for in situ detection of marine invertebrate larvae. Molecular Ecology Resources, 8:540-550.

Kerckhof F, Haelters J and Gollasch J. 2007. Alien species in the marine and brackish ecosystem: the situation in Belgian waters. Aquatic invasions, 2(3):243-257.

Leung B, Lodge DM, Finnoff D, Shogren JF, Lewis MA and Lamberti G. 2002. An ounce of prevention or a pound of cure: bioeconomic risk analysis of invasive species. Proceedings: Biological Sciences, 269:2407-2413.

Matsui M, Honjo M and Kawabata Z. 2001. Estimation of the fate of dissolved DNA in thermally stratified lake water from the stability of exogenous plasmid DNA. Aquatic Microbial Ecololgy, 26:95-102.

Molnar JL, Gamboa RL, Revenga C and Spalding MD. 2008. Assessing the global threat of invasive species to marine biodiversity. Frontiers in Ecology and Environment, 6(9):485-492.

Neill PE et al. 2006. Invasion of Codium fragile ssp. tomentosoides in northern Chile: A new threat for Gracilaria farming. Aquaculture, 259:202.

Nuñez M and Pauchard A. 2010. Biological invasions in developing and developed countries: does one model fit all? Biological Invasions, 12:707.

Olenin S, Minchin D and Daunys D. 2007. Assessment of biopollution in aquatic ecosystems. Marine Pollution Bulletin. 55:379-394.

Olenin., $\mathrm{M}$ et al. 2011. Recommendations on methods for the detection and control of biological pollution in marine coastal waters. Marine Pollution Bulletin 62:25982604.

Palumbi SR. 1996. Nucleic acids II: The polymerase chain reaction. In: Hillis DM, Moritz C, Mable BK (eds) Molecular systematics. Sinauer Associates, Inc, pp. 205-247.

Parker JC. 1966. Bottom fauna study: Distribution and relative abundance of Rangia cuneata. Fish and Wildlife Service Bureau of Commercial Fisheries, 246:35-36.

Parmesan C and Yohe G. 2003. A globally coherent fingerprint of climate change impacts across natural systems. Nature, 421(6918):37-42.

Pfitzenmeyer HT and Drobeck KG. 1964. The Occurrence of the Brackish Water Clam, Rangia cuneata, in the Poto_mac River, Maryland. Chesapeake Science, 5(4):209-215. 
Ardura A., Zaiko A., Martinez J.L., Samuiloviene A., Semenova A., Garcia-Vazquez E. 2015. eDNA and specific primers for early detection of invasive species- a case study on the bivalve Rangia cuneata, currently spreading in Europe. Marine Environmental Research, 112(B): 48-55.

doi:10.1016/j.marenvres.2015.09.013

Pochon X, Bott NJ, Smith LF and Wood SA. 2013. Evaluating detection limits of Next-Generation Sequencing for the surveillance and monitoring of international marine pests. PLoS One 8:e73935. doi:73910.71371/journal.pone.0073935.

Pradillon F, Schmidt A, Peplies J and Dubilier N. 2007. Species identification of marine invertebrate early stages by whole-larvae in situ hybridisation of $18 \mathrm{~S}$ ribosomal RNA. Marine Ecology Progress Series, 333:103-116.

Rudinskaya LV and Gusev AA. 2012. Invasion of the North American Wedge Clam Rangia cuneata (G.B. Sowerby I, 1831) (Bivalvia: Mactridae) in the Vistula Lagoon of the Baltic Sea. Russian Journal of Biological Invasions, 3(3):220-229.

Ruiz GM, Fofonoff P, Hines AH and Grosholz ED. 1999. Non-indigenous species as stressors in estuarine and marine communities. Assesing the impacts and interactions. Limnology and Oceonagraphy, 44:950-972.

Seo C, Thorne JH, Hannah L and Thuiller W. 2009. Scale effects in species distribution models: implications for conservation planning under climate change. Biology Letters, 5(1):39-43.

Solovjeva S. 2014. Finding of new mollusk species Rangia cuneata (G.B.Sowerby I, 1831) (Bivalvia: Mactridae) in the Lithuanian coastal waters. Environmental Protection Agency, Lithuania. http://gamta.1t/cms/index?rubricId=d42d35cd-63cd4800-9cfd-86ef9f305dac (in Lithuanian).

Taberlet $\mathrm{P}$ et al. 2007. Power and limitations of the chloroplast trnL (UAA) intron for plant DNA barcoding. Nucleic Acids Research 35:e14. doi:10.1093/nar/gk1938.

Taberlet et al. 2012. Environmental DNA. Molecular Ecology 21:1789-1793.

Thompson JD, Higgins DG and Gibson TJ. 1994. ClustalW-improving the sensitivity of progressive multiple sequence alignment through sequence weighting, position-specific gap penalties and weight matrix choice. Nucleic Acids Research, $22: 4673-4680$.

Thomsen et al. 2012. Detection of a Diverse Marine Fish Fauna Using Environmental DNA from Seawater Samples. PLoS ONE 7(8):e41732.

Valentine JF and Sklenar SA. 2004. Mobile-Tensaw Delta hydrological modifications impact study. Final Report to the Mobile Bay National Estuary Program. $139 \mathrm{p}$.

Verween A, Kerckhof F, Vincx M and Degraer S. 2006. First European record of the invasive brackish water clam Rangia cuneata (G.B. Sowerby I, 1831) (Mollusca: Bivalvia). Aquatic Invasions, 1(4):198-203.

Wakida-Kusunoki AT and MacKenzie CL. 2004. Rangia and Marsh clams, Rangia cuneata, R. flexuosa and Polymesoda caroliniana, in Eastern Mexico: Distribution, biology and ecology, and historical fisheries. Marine Fisheries Review, 66 (3):13-20.

Willerslev E et al. 2003. Diverse plant and animal DNA from Holocene and Pleistocene sedimentary records. Science, 300:792-795.

Wolff WJ. 1999. Exotic invaders of the meso-oligohaline zone of estuaries in the Netherlands: why are there so many? Helgolander Meeresunters, 52:393-400. 
Ardura A., Zaiko A., Martinez J.L., Samuiloviene A., Semenova A., Garcia-Vazquez E. 2015. eDNA and specific primers for early detection of invasive species- a case study on the bivalve Rangia cuneata, currently spreading in Europe. Marine Environmental Research, 112(B): 48-55.

doi:10.1016/j.marenvres.2015.09.013

\section{Figure legends:}


Ardura A., Zaiko A., Martinez J.L., Samuiloviene A., Semenova A., Garcia-Vazquez E. 2015. eDNA and specific primers for early detection of invasive species- a case study on the bivalve Rangia cuneata, currently spreading in Europe. Marine Environmental Research, 112(B): 48-55.

doi:10.1016/j.marenvres.2015.09.013
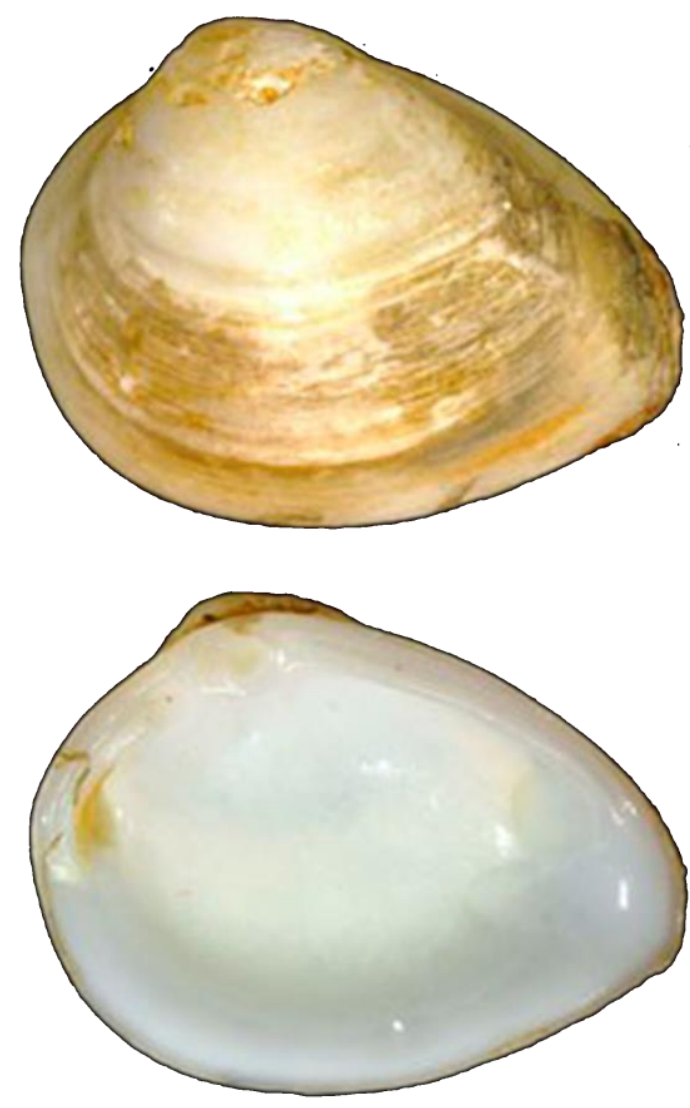

Figure 1. Rangia cuneata specimen, from World Register of Marine Species (WORMS, www.marinespecies.org) 
Ardura A., Zaiko A., Martinez J.L., Samuiloviene A., Semenova A., Garcia-Vazquez E. 2015. eDNA and specific primers for early detection of invasive species- a case study on the bivalve Rangia cuneata, currently spreading in Europe. Marine Environmental Research, 112(B): 48-55.

doi:10.1016/j.marenvres.2015.09.013

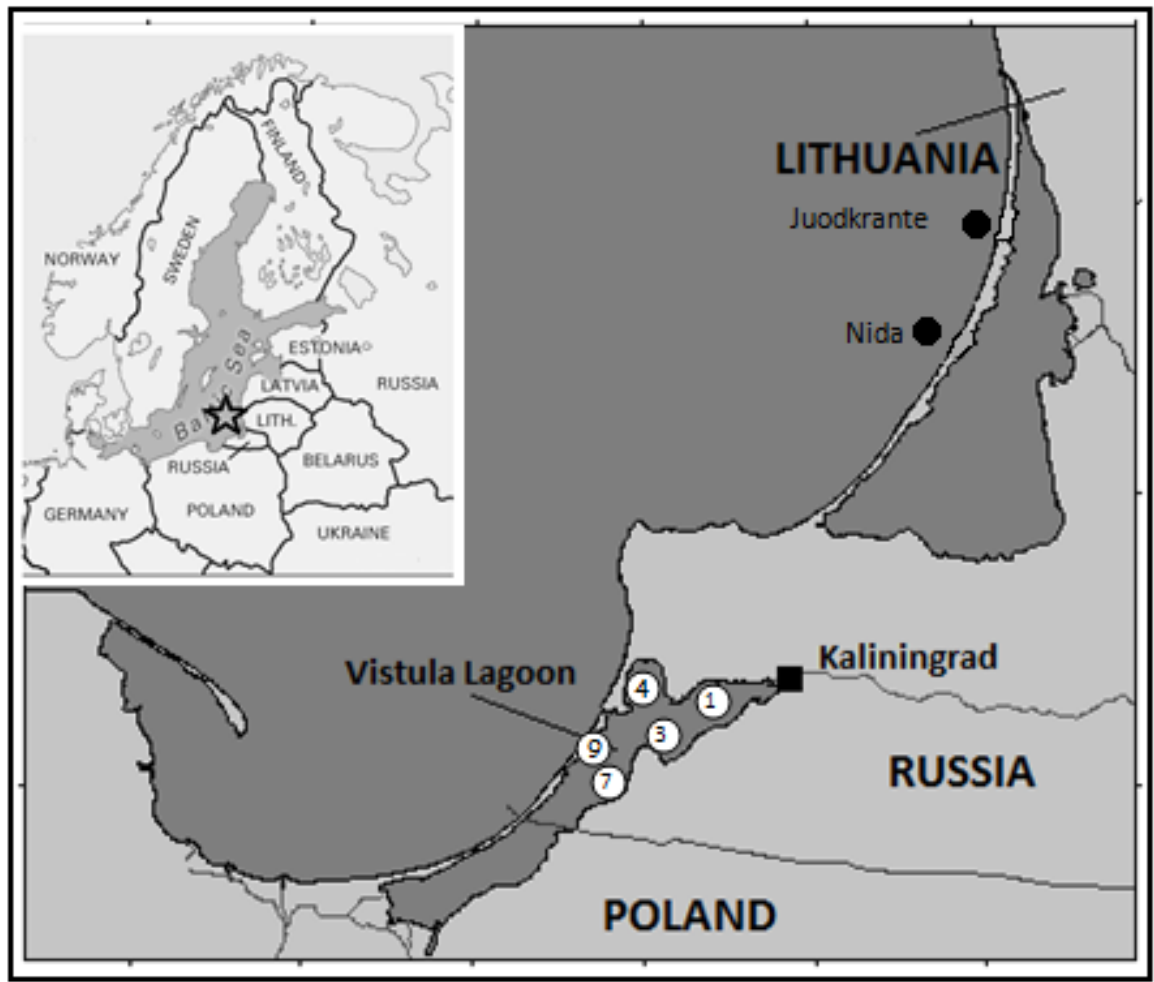

Figure 2. Map of the sampling area. Sampling sites in Vistula Lagoon (Stations 1, 3, 4, 7 and 9) and in the Baltic Sea in the Lithuanian coast (Juodkrante and Nida). 
Ardura A., Zaiko A., Martinez J.L., Samuiloviene A., Semenova A., Garcia-Vazquez E. 2015. eDNA and specific primers for early detection of invasive species- a case study on the bivalve Rangia cuneata, currently spreading in Europe. Marine Environmental Research, 112(B): 48-55.

\section{doi:10.1016/j.marenvres.2015.09.013}

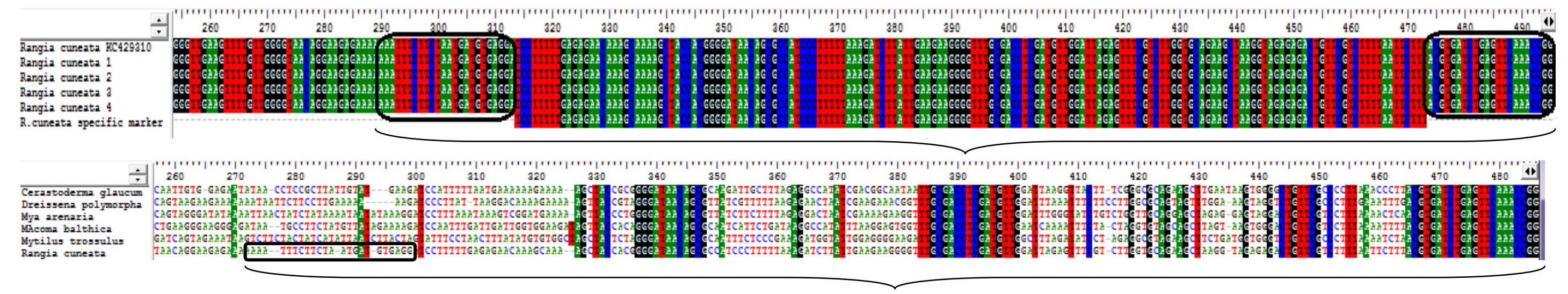

Figure 3. Rangia cuneata-specific primer design. Alignment obtained from ClustalW tool included in BioEdit software.

Upper part: alignment between different sequences of Rangia cuneata including one from GenBank (KC429310).

Bottom part: alignment between 6 different mollusks species: Cerastoderma glaucum, Dreissena polymorpha, Mya arenaria, Macoma

balthica, Mytilus trossulus and Rangia cuneata.

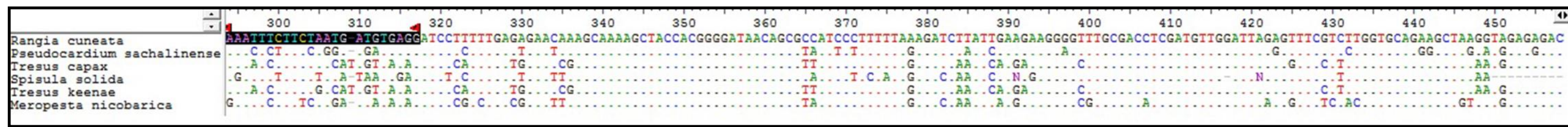

Figure 4. Alignment obtained with ClustalW tool included in BioEdit software, for $16 \mathrm{~S}$ ribosomal RNA genes of different species taxonomically close to Rangia cuneata available in GenBank. 
Ardura A., Zaiko A., Martinez J.L., Samuiloviene A., Semenova A., Garcia-Vazquez E. 2015. eDNA and specific primers for early detection of invasive species- a case study on the bivalve Rangia cuneata, currently spreading in Europe. Marine Environmental Research, 112(B): 48-55.

doi:10.1016/j.marenvres.2015.09.013

a)

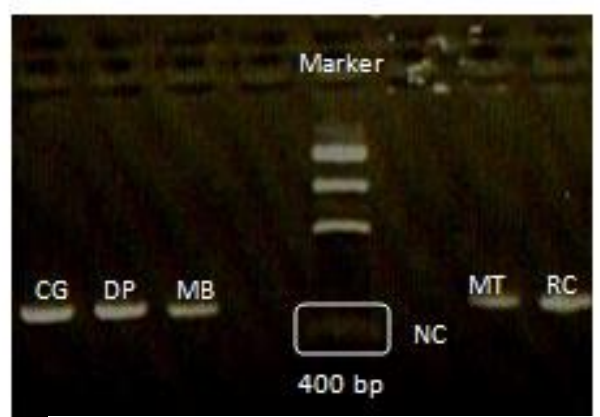

b)

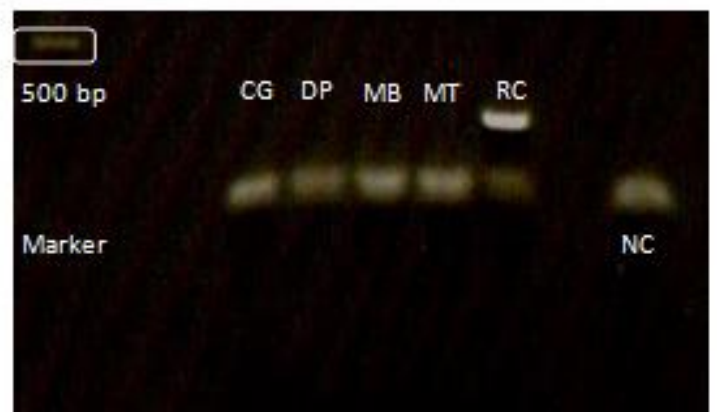

Figure 5: a) Agarose gel of PCR products with universal primers (Palumbi, 1996) from C. glaucum (CG), D. polymorpha (DP), M. balthica (MA), M. trossulus (MT) and Rangia cuneata (RC). NC: negative control. Marker: Low DNA Mass Ladder. b) Agarose gel of PCR products with Rangia cuneata-specific primers from C. glaucum (CG), D. polymorpha (DP), M. balthica (MA), M. trossulus (MT) and Rangia cuneata (RC). NC: negative control. Marker: Low DNA Mass Ladder.

a)

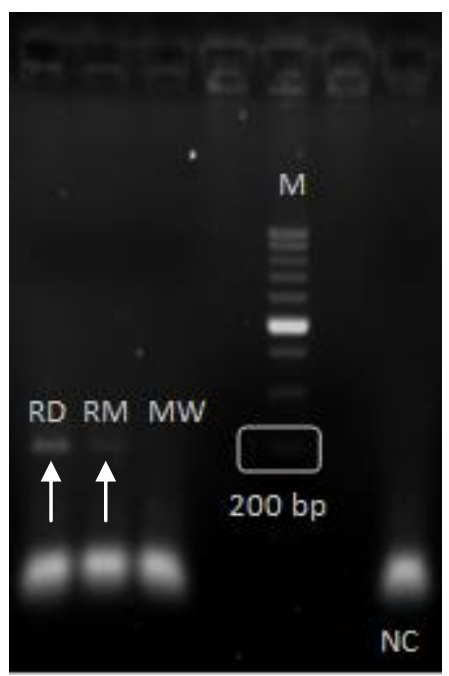

b)

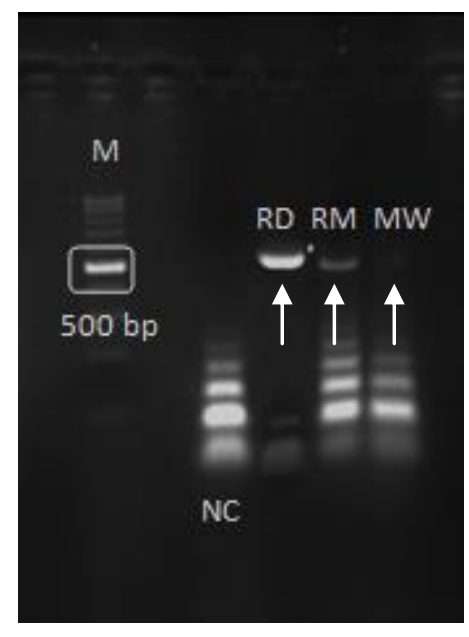

Figure 6: a) Agarose gel of PCR products obtained with Rangia cuneata-specific primers. RD: Rangia cuneata in distilled water, RM: Rangia cuneata in marine water from Ria de Aviles (North Spain), MW: marine water from Ria de Aviles (North Spain) without Rangia cuneata. NC: negative control. M: DNA size marker 100 bp ladder. Positive results can be visualized with white arrows. b) Agarose gel of PCR products obtained with universal Palumbi primers (1996). RD: Rangia cuneata in distilled water, RM: Rangia cuneata in marine water from Ria de Aviles (North Spain), MW: marine water from Ria de Aviles (North Spain) without Rangia cuneata. NC: negative control. M: DNA size marker 100 bp ladder. Positive results can be visualized with white arrows. 
Ardura A., Zaiko A., Martinez J.L., Samuiloviene A., Semenova A., Garcia-Vazquez E. 2015. eDNA and specific primers for early detection of invasive species- a case study on the bivalve Rangia cuneata, currently spreading in Europe. Marine Environmental Research, 112(B): 48-55.

doi:10.1016/j.marenvres.2015.09.013

a)

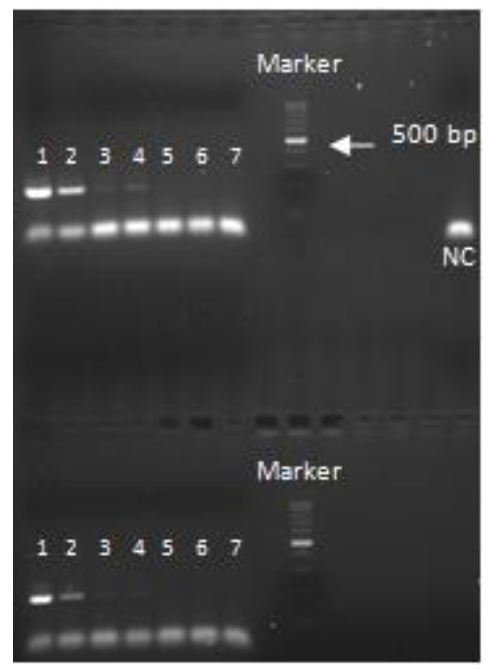

b)

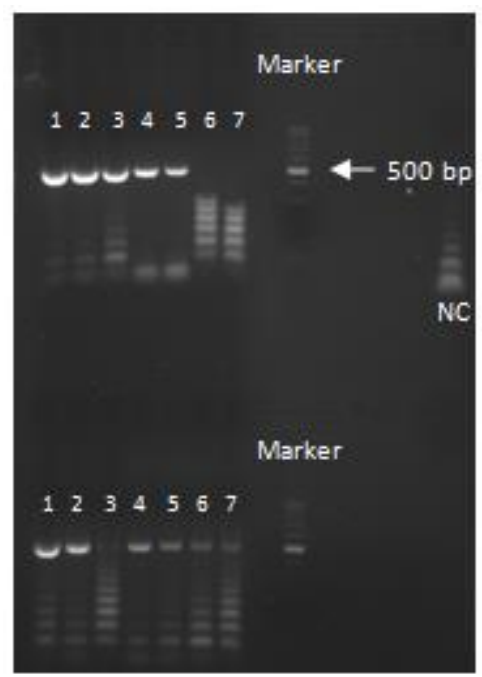

Figure 7.

a) Agarose gel of PCR products obtained with Rangia cuneata-specific primers.

Upper part: Serial dilutions 1:5 to $1: 15,625$ of Rangia cuneata in distilled water (1-7). NC: negative control. Marker: DNA size marker 100 bp ladder Bottom part: Serial dilutions $1: 5$ to $1: 15,625$ of Rangia cuneata together with 50 $\mathrm{ng} / \mu \mathrm{l}$ of each other 5 mollusks (1-7). Marker: DNA size marker $100 \mathrm{bp}$ ladder.

b) Agarose gel of PCR products obtained with Universal primers (Palumbi, 1996).

Upper part: Serial dilutions 1:5 to 1:1,000 of Rangia cuneata in distilled water (1-7). NC: negative control. Marker: DNA size marker 100 bp ladder

Bottom part: Serial dilutions 1:5 to 1:1,000 of Rangia cuneata with $50 \mathrm{ng} / \mu \mathrm{l}$ of each other 5 mollusks (1-7). Marker: DNA size marker 100 bp ladder. 
Ardura A., Zaiko A., Martinez J.L., Samuiloviene A., Semenova A., Garcia-Vazquez E. 2015. eDNA and specific primers for early detection of invasive species- a case study on the bivalve Rangia cuneata, currently spreading in Europe. Marine Environmental Research, 112(B): 48-55.

doi:10.1016/j.marenvres.2015.09.013

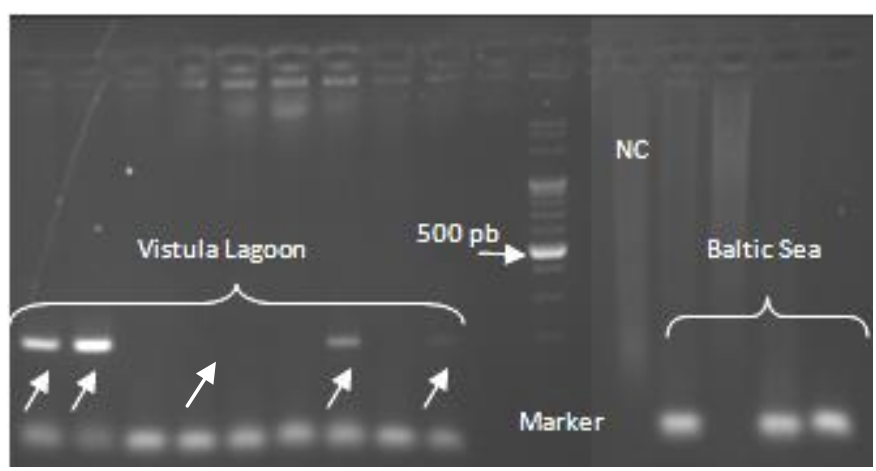

Figure 8. Agarose gel of PCR products obtained with Rangia cuneata-specific primers in water samples from Vistula Lagoon and Baltic Sea. Positive results can be visualized with white arrows. Marker: DNA size marker 100 bp ladder. NC: negative control. 
Ardura A., Zaiko A., Martinez J.L., Samuiloviene A., Semenova A., Garcia-Vazquez E. 2015. eDNA and specific primers for early detection of invasive species- a case study on the bivalve Rangia cuneata, currently spreading in Europe. Marine Environmental Research, 112(B): 48-55.

doi:10.1016/j.marenvres.2015.09.013

\begin{tabular}{|c|c|c|c|c|c|c|c|}
\hline & Date & Location & $\begin{array}{l}\text { Sample } \\
\text { code }\end{array}$ & $\begin{array}{l}\text { Water } \\
\text { temperature, } \\
{ }^{\circ} \mathrm{C}\end{array}$ & $\begin{array}{l}\text { Salinity, } \\
\text { PSU }\end{array}$ & Latitude & Longitud \\
\hline \multirow{4}{*}{ 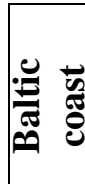 } & 20140520 & Juodkrante & BS1.1 & 5.54 & 7.3 & $55^{\circ} 32^{\prime} 57.49^{\prime \prime}$ & $21^{\circ} 07^{\prime} 14.28^{\prime \prime}$ \\
\hline & 20140520 & Nida & BS2.1 & 5.21 & 7.3 & $55^{\circ} 18^{\prime} 11.72^{\prime \prime}$ & $21^{\circ} 00^{\prime} 05.75^{\prime \prime}$ \\
\hline & 20140902 & Juodkrante & BS1.2 & 17.43 & 7.00 & $55^{\circ} 32^{\prime} 57.49^{\prime \prime}$ & $21^{\circ} 07^{\prime} 14.28^{\prime \prime}$ \\
\hline & 20140902 & Nida & BS2.2 & 17.48 & 7.00 & $55^{\circ} 18^{\prime} 11.72^{\prime \prime}$ & $21^{\circ} 00^{\prime} 05.75^{\prime \prime}$ \\
\hline \multirow{9}{*}{ 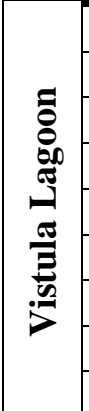 } & 20140604 & Station 1 & V1.1 & 17.28 & 3.7 & $54^{\circ} 39^{\prime} 32.02^{\prime \prime}$ & $20^{\circ} 10^{\prime} 34.36^{\prime \prime}$ \\
\hline & & Station 3 & V2.1 & 17.85 & 4.0 & $54^{\circ} 34^{\prime} 52.00^{\prime \prime}$ & $20^{\circ} 02^{\prime} 26.68^{\prime \prime}$ \\
\hline & & Station 7 & V3.1 & 17.65 & 4.3 & $54^{\circ} 31^{\prime} 32.33^{\prime \prime}$ & $19^{\circ} 56^{\prime} 17.32^{\prime \prime}$ \\
\hline & & Station 9 & V4.1 & 17.31 & 4.2 & $54^{\circ} 34^{\prime} 19.42^{\prime \prime}$ & $19^{\circ} 51^{\prime} 47.04^{\prime \prime}$ \\
\hline & 20140722 & Station 1 & V1.2 & 22.66 & 4.3 & $54^{\circ} 39^{\prime} 32.02^{\prime \prime}$ & $20^{\circ} 10^{\prime} 34.36^{\prime \prime}$ \\
\hline & & Station 3 & V2.2 & 23.41 & 4.9 & $54^{\circ} 34^{\prime} 52.00^{\prime \prime}$ & $20^{\circ} 02^{\prime} 26.68^{\prime \prime}$ \\
\hline & & Station 4 & V5.2 & 23.12 & 4.9 & $54^{\circ} 40^{\prime} 08.82^{\prime \prime}$ & $19^{\circ} 59^{\prime} 23.92^{\prime \prime}$ \\
\hline & & Station 7 & V3.2 & 23.89 & 4.2 & $54^{\circ} 31^{\prime} 32.33^{\prime \prime}$ & $19^{\circ} 56^{\prime} 17.32^{\prime \prime}$ \\
\hline & & Station 9 & V4.2 & 23.43 & 4.9 & $54^{\circ} 34^{\prime} 19.42^{\prime \prime}$ & $19^{\circ} 51^{\prime} 47.04^{\prime \prime}$ \\
\hline
\end{tabular}

Table 1. Environmental samples (locations, dates and abiotic conditions) 
Ardura A., Zaiko A., Martinez J.L., Samuiloviene A., Semenova A., Garcia-Vazquez E. 2015. eDNA and specific primers for early detection of invasive species- a case study on the bivalve Rangia cuneata, currently spreading in Europe. Marine Environmental Research, 112(B): 48-55.

doi:10.1016/j.marenvres.2015.09.013

\begin{tabular}{|c|c|c|c|c|}
\hline & \multicolumn{2}{|c|}{ Rangia cuneata primers } & \multicolumn{2}{|c|}{ Universal primers } \\
\hline DNA Mixture & $\begin{array}{c}\text { Serial dilutions } \\
\text { of Rangia } \\
\text { cuneata DNA }\end{array}$ & $\begin{array}{c}\text { PCR } \\
\text { amplification }\end{array}$ & $\begin{array}{c}\text { Serial dilutions } \\
\text { of } \text { Rangia } \\
\text { cuneata DNA }\end{array}$ & $\begin{array}{c}\text { PCR } \\
\text { amplification }\end{array}$ \\
\hline \multirow{7}{*}{$\begin{array}{c}\text { Rangia cuneata in variable } \\
\text { concentrations; } 50 \mathrm{ng} / \mu \mathrm{l} \text { of } \\
\text { each Cerastoderma glaucum, } \\
\text { Dreissena polymorpha, } \\
\text { Macoma balthica, Mya } \\
\text { arenaria, Mytilus trossulus }\end{array}$} & 1 & + & 1 & + \\
\hline & $1: 5$ & + & $1: 5$ & + \\
\hline & $1: 25$ & + & $1: 10$ & + \\
\hline & $1: 125$ & + & $1: 50$ & + \\
\hline & $1: 625$ & - & $1: 100$ & + \\
\hline & $1: 3125$ & - & $1: 500$ & + \\
\hline & $1: 15625$ & - & $1: 1000$ & + \\
\hline \multirow{8}{*}{ Only Rangia cuneata } & 0 & - & 0 & - \\
\hline & 1 & + & 1 & + \\
\hline & $1: 5$ & + & $1: 5$ & + \\
\hline & $1: 25$ & + & $1: 10$ & + \\
\hline & $1: 125$ & + & $1: 50$ & + \\
\hline & $1: 625$ & - & $1: 100$ & + \\
\hline & $1: 3125$ & - & $1: 500$ & - \\
\hline & $1: 15625$ & - & $1: 1000$ & - \\
\hline
\end{tabular}

Table 2: Results of the serial dilutions of Rangia cuneata DNA; with DNA mixture from the other five mollusks species analyzed (upper part), and in distilled water (bottom part). Number 1 in serial dilutions corresponds to $50 \mathrm{ng} / \mu \mathrm{l}$ of Rangia cuneata and 0 is the negative control (no Rangia cuneata DNA). The table presents the different results of PCR amplifications (+: positive and -: negative) with Rangia cuneata primers, described in this work, and with universal primers described by Palumbi (1996). 
Ardura A., Zaiko A., Martinez J.L., Samuiloviene A., Semenova A., Garcia-Vazquez E. 2015. eDNA and specific primers for early detection of invasive species- a case study on the bivalve Rangia cuneata, currently spreading in Europe. Marine Environmental Research, 112(B): 48-55.

doi:10.1016/j.marenvres.2015.09.013

\begin{tabular}{|c|c|c|}
\cline { 2 - 3 } \multicolumn{1}{c|}{} & \multicolumn{2}{c|}{ PCR AMPLIFICATION } \\
\cline { 2 - 3 } \multicolumn{1}{c|}{} & $\begin{array}{c}\text { Rangia cuneata } \\
\text { primers }\end{array}$ & Universal primers \\
\hline $5 \mathrm{mg} \mathrm{Rc} / 50 \mathrm{ml}$ distilled water & + & + \\
\hline $5 \mathrm{mg} \mathrm{Rc} / 50 \mathrm{ml}$ marine water & + & + \\
\hline $\mathbf{5 0} \mathbf{~ m l}$ marine water & - & + \\
\hline Negative control with distilled water & - & - \\
\hline
\end{tabular}

Table 3: Marker validation in Simulated Communities. PCR results (+: positive and -: negative) with Rangia cuneata primers and with universal primers described by Palumbi (1996) in different samples: $5 \mathrm{mg}$ of dry weight of Rangia cuneata (Rc) in 50 $\mathrm{ml}$ of distilled water and in marine water from Ria de Aviles (North Spain), one control with $50 \mathrm{ml}$ of the same marine water without Rangia cuneata and one negative control only with distilled water. 
Ardura A., Zaiko A., Martinez J.L., Samuiloviene A., Semenova A., Garcia-Vazquez E. 2015. eDNA and specific primers for early detection of invasive species- a case study on the bivalve Rangia cuneata, currently spreading in Europe. Marine Environmental Research, 112(B): 48-55.

doi:10.1016/j.marenvres.2015.09.013

\begin{tabular}{|c|c|c|c|c|c|}
\hline \multirow[b]{2}{*}{ Location } & \multirow[b]{2}{*}{$\begin{array}{l}\text { Rangia cuneata larvae } \\
\text { density, ind } / \mathrm{m}^{3}\end{array}$} & \multicolumn{2}{|c|}{ Sample 1st semester 2014} & \multicolumn{2}{|c|}{ Sample 2nd semester 2014} \\
\hline & & $\begin{array}{c}\text { DNA conc. } \\
(\mathrm{ng} / \mu \mathrm{l})\end{array}$ & $\begin{array}{l}\text { Rangia cuneata } \\
\text { PCR product } \\
(\mathrm{ng} / \mu \mathrm{l})\end{array}$ & $\begin{array}{c}\text { DNA conc. } \\
(\mathrm{ng} / \mu \mathrm{l})\end{array}$ & $\begin{array}{l}\text { Rangia cuneata } \\
\text { PCR product } \\
(\mathrm{ng} / \mu \mathrm{l})\end{array}$ \\
\hline BS1 & Not detected & 447 & No & 269 & No \\
\hline BS2 & Not detected & 677 & No & 238 & No \\
\hline V1 & 6791 & 41 & 50 & 45 & No \\
\hline $\mathrm{V} 2$ & 3058 & 25 & 50 & 29 & No \\
\hline V3 & 1168 & 11 & No & 33 & No \\
\hline V4 & 1946 & 14 & 6 & 29 & 20 \\
\hline V5 & 20262 & - & - & 35 & 40 \\
\hline
\end{tabular}

Table 4. Marker validation in field water samples from Baltic Sea and Vistula Lagoon. Date of the recollection, abbreviation of each sample, DNA concentration of each one (ng/ $\mu \mathrm{l})$, concentration of Rangia cuneata PCR product obtained with Rangia cuneataspecific primers (ng/ $\mu \mathrm{l})$ and Rangia cuneata observed larvae density. 
Ardura A., Zaiko A., Martinez J.L., Samuiloviene A., Semenova A., Garcia-Vazquez E. 2015. eDNA and specific primers for early detection of invasive species- a case study on the bivalve Rangia cuneata, currently spreading in Europe. Marine Environmental Research, 112(B): 48-55.

doi:10.1016/j.marenvres.2015.09.013

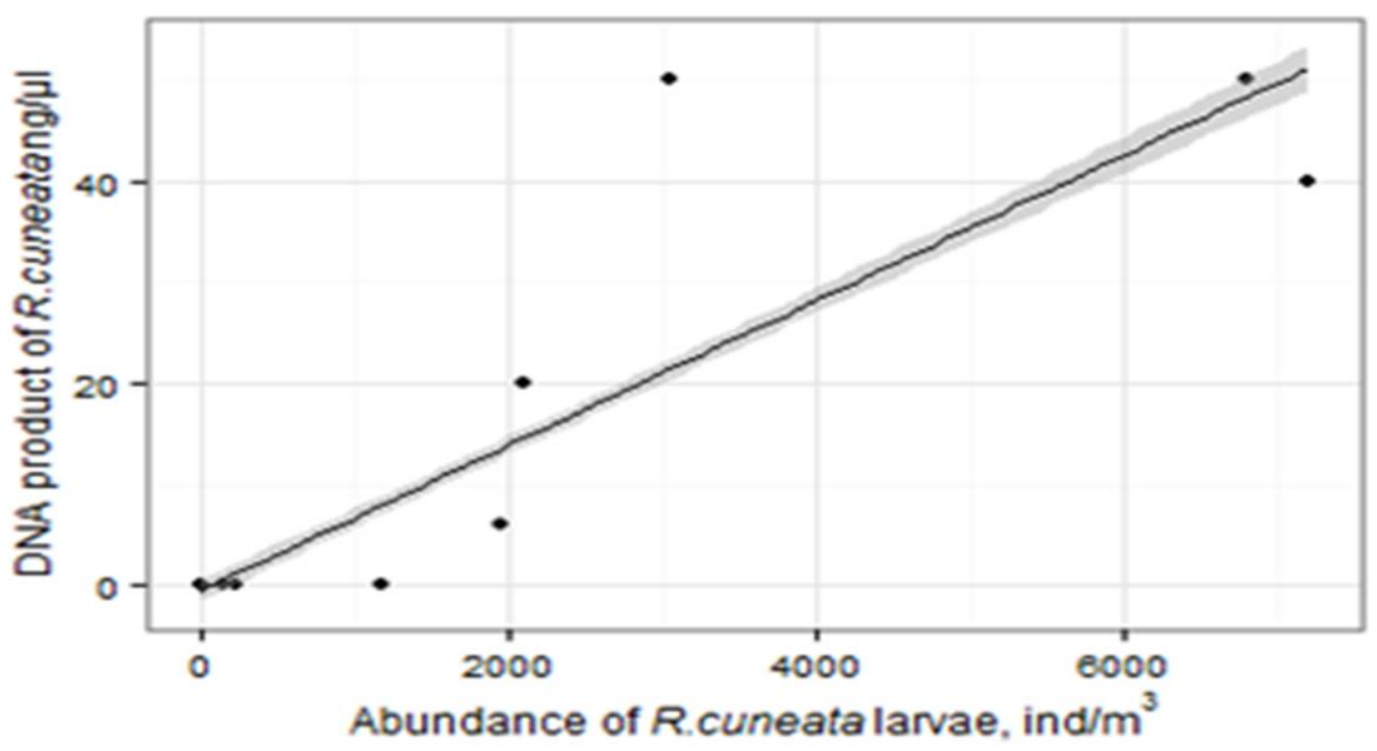

Supplementary Figure 1: Quantified Rangia cuneata DNA products from PCR amplifications with designed markers (validation on eDNA from the Baltic coast and the Vistula Lagoon abundance) versus larvae abundance from the visual analysis with fitted linear model trendline $(\mathrm{R} 2=77.94 \%, \mathrm{r}=0.88, \mathrm{p}<0.001)$ and standard error represented by shaded area. 
Ardura A., Zaiko A., Martinez J.L., Samuiloviene A., Semenova A., Garcia-Vazquez E. 2015. eDNA and specific primers for early detection of invasive species- a case study on the bivalve Rangia cuneata, currently spreading in Europe. Marine Environmental Research, 112(B): 48-55.

\begin{tabular}{|c|c|c|}
\hline doi:10.1CScientific name $015.09 .01 \beta$ & Classification & GenBank AN \\
\hline Gracilaria lemaneiformis & Algae & M54986 \\
\hline Bylgides sarsi & Annelid & JN852891 \\
\hline Hediste diversicolor & Annelid & EU221671 \\
\hline Bufo calamita & Amphibian & AF350430 \\
\hline Corvus corone & Bird & DQ983945 \\
\hline Bugula neritina & Bryozoan & KC130059 \\
\hline Electra crustulenta & Bryozoan & AJ853964 \\
\hline Cylisticus convexus & Crustacean & AJ388101 \\
\hline Oniscus asellus & Crustacean & AJ388090 \\
\hline Porcellio scaber & Crustacean & DQ305104 \\
\hline Anabaena oscillarioides & Cyanobacteria & GQ466544 \\
\hline Pleurocapsales cyanobacterium & Cyanobacteria & HQ416899 \\
\hline Esox lucius & Fish & HM177478 \\
\hline Merluccius merluccius & Fish & DQ274031 \\
\hline Perca fluviatilis & Fish & GU018097 \\
\hline Scorpaena scofra & Fish & EU747071 \\
\hline Monomorium pharonis & Insect & DQ023051 \\
\hline Aurelia aurita & Jellyfish & KC767897 \\
\hline Halichoerus grypus & Mammal & X72004 \\
\hline Pseudokeronopsis flava & Protozoa & DQ227798 \\
\hline Pseudokeronopsis rubra & Protozoa & DQ640314 \\
\hline Iguana iguana & Reptile & AB028756 \\
\hline Asterias forbesi & Starfish & DQ297073 \\
\hline Asterias rubens & Starfish & AY652504 \\
\hline Styela plicata & Tunicate & AM292601 \\
\hline
\end{tabular}

Supplementary Table 1: 16S rDNA sequences representative of a wide range of marine taxonomic groups, including algae, invertebrates and vertebrates retrieved from GenBank. 